AGH DRILLING, OIL, GAS • Vol. 32 • No. $3 \cdot 2015$

http://dx.doi.org/10.7494/drill.2015.32.3.565

Aleksandra Jamrozik*, Jan Ziaja*, Andrzej Gonet*, Jerzy Fijal**

\title{
SELECTED ASPECTS OF DRILLING WASTE MANAGEMENT IN POLAND***
}

\section{INTRODUCTION}

The continuous increase of global demand for energy resources prompts humanity to intensify the onshore and offshore prospecting for petroleum and natural gas. The increased interest in prospecting for and exploration of hydrocarbon deposits from conventional and unconventional sources requires drilling sometimes hundreds of boreholes. Each such activity, no matter the advancement of methods used, leads to environmental degradation. One of such harmful effects is the generation of considerable quantities of drilling wastes.

The waste materials from borehole drilling consist of crushed rock cuttings from the borehole and remnants of the drilling mud. The function of the mud is to lubricate and cool drill bits, stabilize the borehole, control pressure, and bring cuttings up to the platform. Drilling waste also comprises the spent drilling mud that has lost its technical properties [1].

Drilling waste differs in the material it is made of, physicochemical composition and also properties resulting from, e.g. its constituents. Drilling waste generated in the drilling process assumes solid, semi-liquid and liquid forms. Solid waste is basically the cuttings from the whole profile transported with the mud from the bottom of the well to the surface, where they are separated using vibration sieves and other mud-cleaning equipment. Solid waste is also produced while, e.g. cementing casing pipes in the well. Liquid and semi-liquid wastes are mostly waste drilling muds and, to a lesser degree, working fluids which are useless upon the completion of a given stage of drilling. Liquid waste also include technological waters mixed with drilling mud [11].

* AGH University of Science and Technology, Faculty of Drilling, Oil and Gas, Krakow, Poland

** AGH University of Science and Technology, Faculty of Geology, Geophysics and Environmental Protection, Krakow, Poland

*** The investigations have been funded from the Polish-Norwegian Research Program operated by the National Centre for Research and Development under the Norwegian Financial Mechanism 2009-2014 within the framework of the Project Contract No. Pol-Nor/200375/58/2013 


\section{DRILLING WASTE AND ITS CHARACTERISTIC}

The major components of drilling muds are liquid (water, oil, or another organic fluid) and solid (a weighting material, typically barite) components. Various additives are used to improve the technical performance of the mud. Among these are viscosifiers (e.g. polyacrylates and other organic polymers), emulsifiers (e.g. alkylacrylate sulphonate and polyethylene oxide), $\mathrm{pH}$ and shale control agents, and deflocculants. The additives applied vary in different drilling operations and in the course of the drilling itself [1].

The quantity, composition and properties of typical drilling waste generated in the process of drilling and well testing depend particularly on the type of the drilling muds applied, the lithology of rock layers drilled through, and the drilling technology [5].

In Poland most of the drilling works have been currently conducted in the areas of the Polish Lowlands, Pomerania, the Carpathians and the Carpathian Foredeep.

The data from the wells drilled in the Carpathians, the Carpathian Foredeep and the Polish Lowlands were collected and used to establish the dependencies between the amount of the waste generated and the depth of the well. The average indices of drilling waste volumes expressed in cubic meters per $1 \mathrm{r} . \mathrm{m}$. of the well have been grouped in the respective end-depth intervals of the well (Fig. 1) [11].



Fig. 1. Indices of drilling waste generated per 1 r.m. of the well for specific borehole intervals [11]

The analysis of Figure 1 shows that the quantitative indices of the drilling waste totals per $1 \mathrm{r} . \mathrm{m}$. of the well change in the range $0.59-1.34 \mathrm{~m}^{3} / \mathrm{r} . \mathrm{m}$., for liquid waste from 0.40 to $0.95 \mathrm{~m}^{3} / \mathrm{r}$.m., and for solid plus semi solid waste from 0.19 to $0.40 \mathrm{~m} / \mathrm{r} . \mathrm{m}$.

The composition of drilling waste generated in the course of drilling operations within the Polish Lowlands, Pomerania, the Carpathians and the Carpathian Foredeep was also analyzed. The study concentrated on water-based-muds (WBMs), which are most frequently applied in Polish drilling practice, i.e. the bentonite, potassium-polymer, glycol-potassium, polymer-chloride varieties and the clay-free mud for drilling up operations. 
Typically, the modern WBMs contain fresh or salt water as the base fluid, and barite $\left(\mathrm{BaSO}_{4}\right)$ or ilmenite $\left(\mathrm{FeTiO}_{3}\right)$ as a weighting agent. Clays or organic polymers are added to create a homogenous fluid. Other chemicals (e.g. potassium phormate and various glycols) are added to achieve viscosity control, shale stability, cooling and lubrication $[6,10]$. Such muds are complex, multiphase colloidal systems modified with chemical, mineral and organic additives. Their working properties are preserved in spent drilling muds [3].

The analyzed mud waste are colloidal suspensions, being most frequently polymer-mineral microcomposites of diversified chemical and mineral phase compositions and also the participation of a dispersed solid phase [4]. The drilling waste mud in the form of the colloidal system is stable due to such factors as:

- the content of monovalent electrostatic charges of particles making up colloids, which mainly consist of a set of interconnected mineral and organic polymers,

- the size of the hydration covers protecting hydrophilic components of colloidal molecules,

- the share of highly hydrophilic polymers (e.g. derivatives of polyacrylamide, polyglycols and biopolymers).

The electrostatic stabilization of spent drilling muds provides their special properties, e.g. the lack of phase separation or homogeneity. Flocculation of such suspensions is hindered. The phases are kept separated most often with synthetic polymers of a high molecular weight. There are also on-going investigations on new low-molecular cationic copolymers containing amine groups of the first order [12].

The drilling muds form viscous water dispersions having rheological parameters most frequently described by the Herschel-Bulkley model, i.e. the equation for non-Newtonian viscoplastic fluids, whose flows are connected with the formation of new and the destruction of already existing mineral and mineral-polymer structures (decomposition, linking or change of chain conformation). The apparent viscosity of such systems is in the range $30-80 \mathrm{mPa} \cdot \mathrm{s}$, and plastic viscosity $30-70 \mathrm{mPa} \cdot \mathrm{s}$. The yield point being a measure of the size of the structures formed is in the range 12-47 $\mathrm{Pa}$ and the structural strength from 2 to $15 \mathrm{~Pa}$. These values decide on the filtration coefficient in a porous medium of drilling waste. At $\Delta p=0.7 \mathrm{MPa}$ these systems show typically low filtration, producing 2.5 to $15.5 \mathrm{~cm}^{3}$ of the filtrate per $0.5 \mathrm{~h}$.

The measurements of the intensity of the light transmitted and the light multi-dispersed with an optic Turbiscan Lab. Formulation analyzer, have revealed that the spent drilling muds represent concentrated dispersion systems, in which the clearing effect takes place [9].

The effect of increased temperature on waste drilling muds is the reason for thehigher energy of the oscillating movements of the particles making up the colloidal systems, and results in:

- reducing the diameter of hydration rims upon breaking away the $\mathrm{H}_{2} \mathrm{O}$ particles with the weakest, i.e. hydrogen bonds,

- increasing the kinetic energy of colloidal particles and the frequency of their collisions.

Both these factors favor the formation of bonds among the colliding particles. Hence, a fraction of the smallest colloidal particles having the highest speed of oscillation movements overcome the electrostatic repulsive forces and enter into the colloidal structures of large-diameter particles. Consequently, the number of the large-diameter particles increases with the concurrent vanishing of the smallest-diameter ones. 


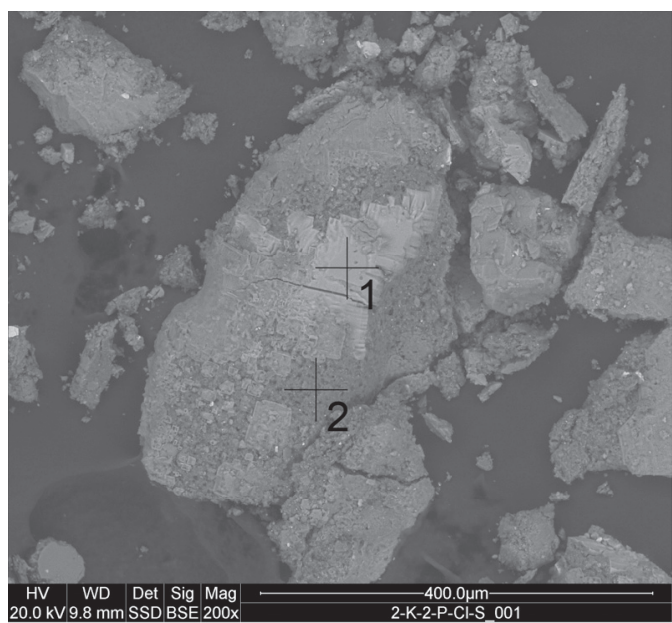

Point 1.

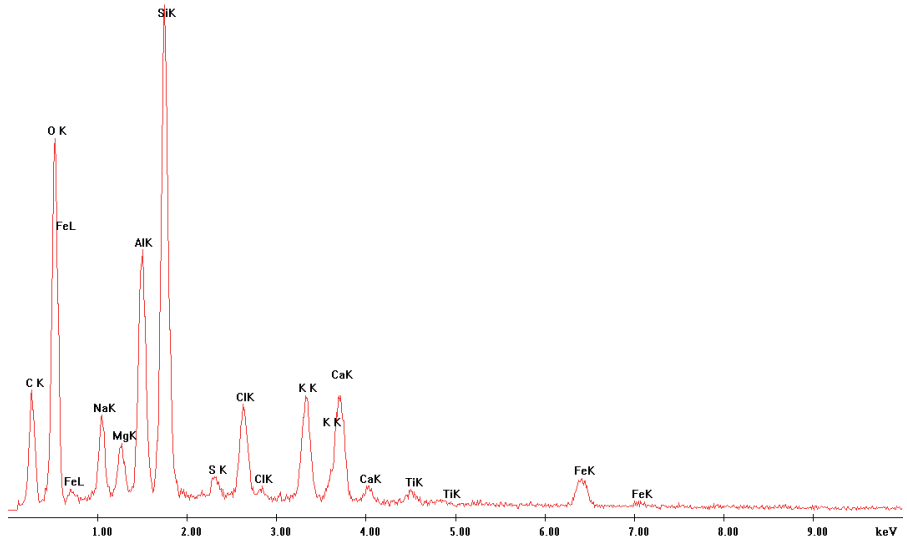

Point 2.



Fig. 2. SEM image of a fragment of a waste polymeric-chloride mud sample documenting the presence of agglomerates formed by the linking of microaggregates composed mainly of clay minerals and calcite crystallites (see an EDS analysis of a microarea at point 2). Agglomerates are incrusted with $\mathrm{KCl}$ crystals (see an EDS analysis of a microarea at point 1) 
The analyses of the phase composition of spent drilling muds performed with the X-ray diffraction and thermal analysis show that the main components of these muds are clay minerals, mainly illite with minor kaolinite, quartz, carbonates in the form of calcite and dolomite, amorphous phases, chlorides in the form of halite and sylvite, sulfates in the form of barite, and organic matter. The content of the organics ranges between 2.0 and $17.0 \mathrm{wt} \%$.

Scanning electron microscopy combined with elemental analyses in microareas revealed a considerable influence of polymeric organic substances on the formation of aggregates and agglomerates. The size of such aggregates is determined by a content of the organic polymers. It certainly results from the crosslinking of single crystallites and small aggregates by chains of organic polymers reacting with active centers on mineral surfaces, especially of clay minerals, via hydrogen bonds, ionic bonds and dispersive forces. An exemplary photogram of a waste polymer-chloride mud is presented in Figure 2.

The results of the physicochemical analyses of the spent drilling muds indicate that prevailing ionic components dissolved in water are chlorides $\left(\mathrm{Cl}^{-}\right)$, sulfates $\left(\mathrm{SO}_{4}^{2-}\right)$ and hydrogen carbonates $\left(\mathrm{HCO}_{3}^{-}\right)$reacting with such ions as $\mathrm{Ca}^{2+}, \mathrm{Mg}^{2+}, \mathrm{Na}^{+}, \mathrm{K}^{+}, \mathrm{Fe}^{2+}, \mathrm{Fe}^{3+}$. They form solutions with the TDS values from about 5 to $25 \mathrm{~g} / \mathrm{dm}^{3}$, and the $\mathrm{Cl}^{-+} \mathrm{SO}_{4}^{2-}$ content from about 0.5 to $99 \mathrm{~g} / \mathrm{dm}^{3}$. The dissolved organic carbon (DOC) content ranges from about 0.25 to about $6.5 \mathrm{~g} / \mathrm{dm}^{3}$. The spent drilling muds reveal a low Eh potential, high chemical oxygen demand (ChOD), and electrolytic conductivity from about 9 to $226 \mathrm{mS} / \mathrm{cm}$. They form solutions of $\mathrm{pH}$ from 7 to 11 .

The spent drilling muds contain amounts of barium $(\mathrm{Ba})$ and zinc $(\mathrm{Zn})$ exceeding permissible levels. The barium contents range from 0.470 to $6.400 \mathrm{~g} / \mathrm{kg} \mathrm{d} . \mathrm{m}$., and those of zinc from 53 to $120 \mathrm{mg} / \mathrm{kg}$ d.m. However, only minor fractions of barium $(0.2-3.5 \%)$ and zinc (1.5-29.0\%) can be leached out by water. The remaining parts of zinc and barium, immobilized by clay minerals, remain in the spent muds.

The total of exchangeable cations in the sorption complex of the waste drilling muds indicates a distinct excess of salts of basic cations and the analyses point to buffering properties of such spent muds. These findings clearly result from the mineral composition of the solid waste components, among which clay and carbonate minerals with an admixture of organic matter dominate $[2,8]$. The spent muds containing hybrid associations of clay minerals with organic matter can be applied to the ground stabilization and the modification of soil properties [7].

\section{RESEARCH AIMED AT THE ENVIRONMENTAL IMPACT OF DRILLING WASTE ON GROUNDS AND SOILS}

Prior to selecting the rational method of managing the drilling waste, it is necessary to identify not only the physicochemical properties of the waste materials but also their biological qualities.

The possibility of contaminating the soil and ground environment with some toxic elements contained in the spent drilling muds was analyzed and the influence of the salinity of the soil on the vegetation growth investigated at an example of the cress (Lepidium sativum), the red grass (Festuca rubra) and the chlorophytum Botrydium granulatum strain. 
The growth tests on the cress Lepidium sativum (Fig. 3) and chlorophytum Botrydium granulatum strain were based on determining the maximum concentration of the drilling mud in soil at which the plants can grow. For this purpose the waste muds were mixed with brown soil at the $1 / 2^{n}$ ratio $(1: 2,1: 4,1: 16$ etc.). The pot tests were conducted on the red grass Festuca rubra. In this case a series of soils with increasing amounts of the spent muds additive was used (Fig. 4).

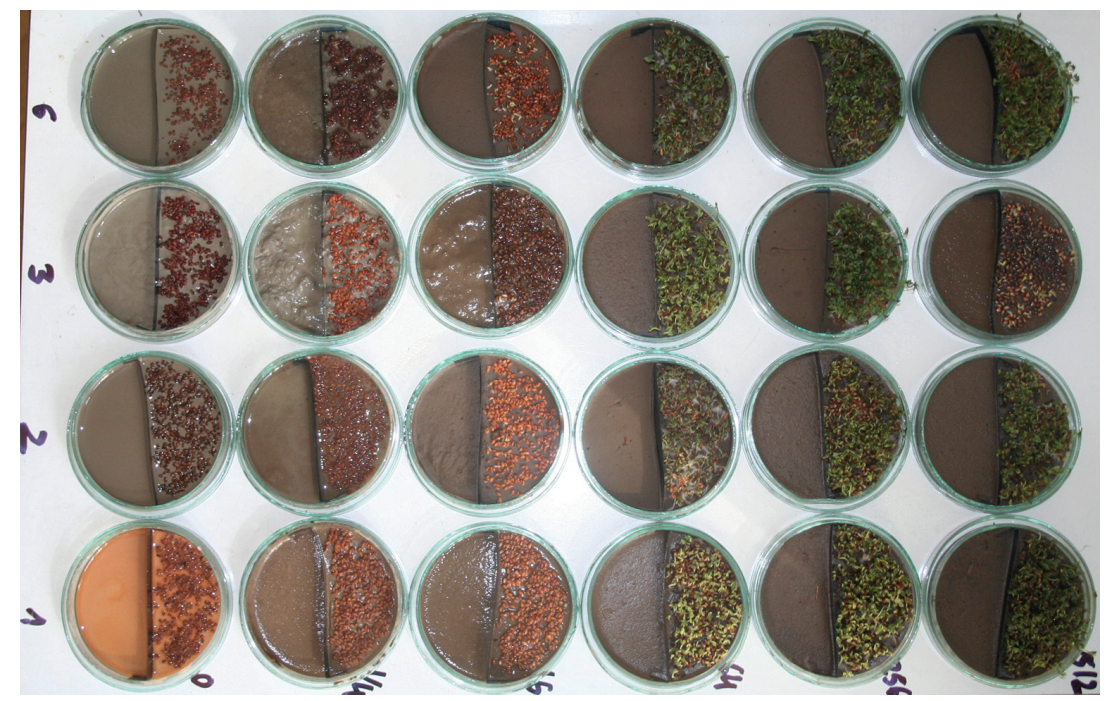

Fig. 3. Growth of Lepidium sativum using waste muds properly mixed with brown soil at the ratios $1: 16$ to $1: 64$

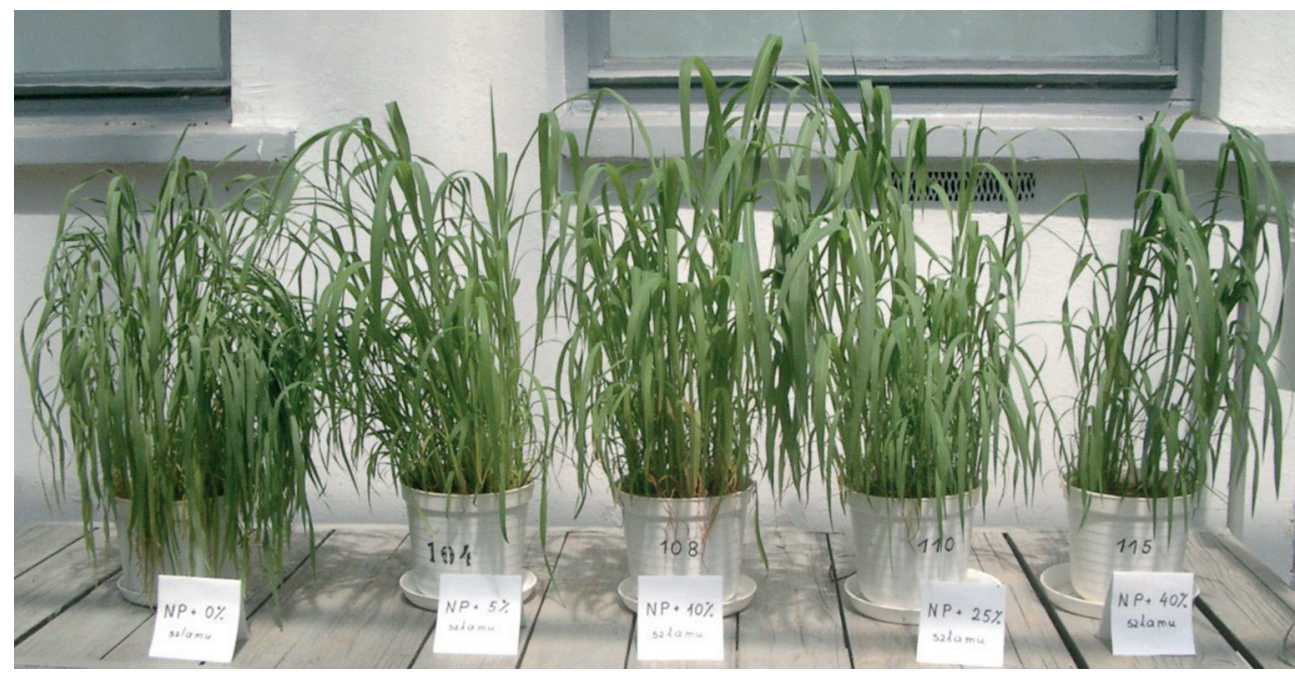

Fig. 4. Red grass Festuca rubra seven weeks old tested on mixtures of soil with various drilling waste added as the starting substrates 
The growth tests on Lepidium sativum and Botrydium granulatum strain show that the growth process began when the drilling muds were mixed with brown soil in the ratios from 1: 16 to 1: 64 (the proportion depends on the waste mud used). Introducing the waste mud admixtures into soil results in lowering the growth of Festuca rubra, especially immediately after spiking the soils with the waste muds.

The changes of the chemical composition of plants grown on soils with waste mud admixtures were also observed. The highest changes were noted for sodium (its concentration in the analyzed plant increased almost 5-fold) and potassium (its elementary content in the dry mass exceeded $6 \mathrm{wt} \%$ ). In the future, the increased potassium content will be neutralized by the plant growth consumption over a maximum of three years. Leaching of sodium from the soils into groundwater and cleaning the soil will from excessive quantities of this element through the increased growth consumption of the plants will be a much longer process taking many years.

It should be stressed that the presence of considerable amounts of mineral colloids introduced with waste drilling muds into soils will result in a deteriorating water/air conditions of such soils, lowering their porosity and maintaining their reduced conditions. The first plants to be grown on soils which were admixed with a waste drilling mud should be grasses. These plants are perennial and in the topmost layer $(0$ to $0.1 \mathrm{~m})$, in which they develop most of their root system, the air conditions are the best and the soil salinity the lowest.

\section{CONCLUSIONS}

Numerous methods of managing drilling waste materials are currently applied, e.g. their solidification and stabilization, underground injections to the rock mass, thermal treatment, extraction of hydrocarbons, bioremediation, reinjection, and disposal at landfills.

The results of some investigations [7] have revealed that waste drilling materials can be used as a mineral additive of the industrial pozzolan character, which is a potential component of cement slurries utilized in hole injection methods. Simultaneously, these slurries meet the standard requirements of the injection slurries used in the cementing of the casing columns and in other sealing/reinforcing drilling operations, and also those controlling the quality of effluents introduced into the water/soil environment.

An addition of calcined mud waste products into cement slurries results in the crystallization of the chloride-modified CSH phase that forms intergrowths with hydrogrossular and irregular carbonate grains (calcite and dolomite) (Fig. 5, points 1 and 2) [7].

Despite the fact that numerous techniques of managing spent drilling muds are known and applied, new ones, which would involve cheaper and more environmentally friendly solutions are still being sought for.

One of the interesting options seems to be the manufacturing of "soil composites". The addition of the magnesium-lime complex with humus into spent drilling muds allows maintaining their higher permeability at the $50 \%$ water saturation of the mixture. The positive result of complexation still requires investigating other practical aspects of the waste utilization.

It should be remembered that spent drilling materials are strongly hydrated, therefore prior to utilizing this type of waste should be brought to a similar level of consistency as that of the natural grounds. 


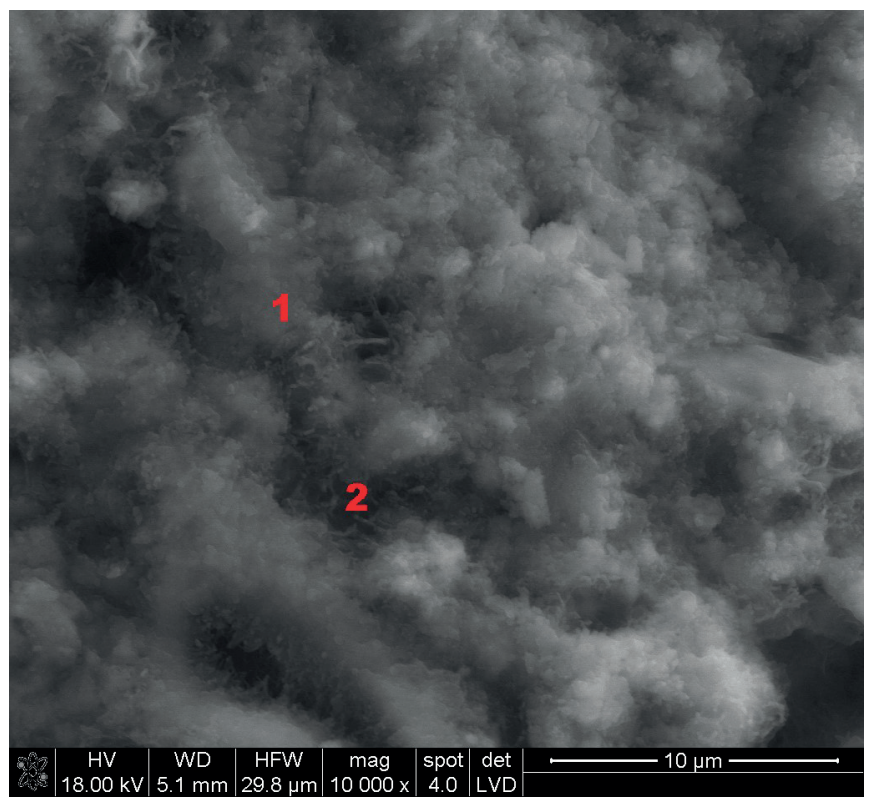

Fig. 5. SEM image of a fragment of hardened cement slurry based on CEM III A with $20 \%$ of industrial pozzolan (magnified $10000 \times$ ) [7]

This effect can be obtained by dewatering and dehydration of spent drilling muds, after which they will have a lower mass and a lower volume, therefore can be more easily processed. The high degree of dewatering is obtained in high-pressure systems, for instance in belt or chamber presses. The waste is dehydrated in the process of coagulation, flocculation and, finally, filtration of the waste muds. As a result, their weight is reduced to $40-70 \%$ of dry mass, and the product after preliminary detoxification can be used in land reclamation of degraded areas.

In Poland sandy soils occupy a few million hectares. These soils are also lime and magnesium-deficient. The areas of soils degraded by an industrial activity, transformations of the landscape due to development plans, and calamity events still increases. The introduction of spent drilling waste into light soils, poor in colloidal particles, may improve their structure and prevent them from further degradation.

\section{REFERENCES}

[1] Bakke T., Klungsøyr J., Sanni S.: Environmental impacts of produced water and drilling waste discharges from the Norwegian offshore petroleum industry. Marine Environmental Research, vol. 92, 2013, pp. 154-169.

[2] Czekaj L., Fijał J., Grzywnowicz I., Jamrozik A.: Influence of drilling waste on selected physicochemical properties of coherent ground. AGH Drilling, Oil, Gas, vol. 22, no. 1, 2005, pp. 111-116. 
[3] Czekaj L., Fijał J., Gonet A., Stryczek S., Grzywnowicz I., Macnar K.: Detoxication of Drilling Waste Contaminated with Oil Products and their Management in Ground Environment on the Example of Podkarpacie District. Mineralogia Polonica - Special Papers, vol. 33, p. 51 [Mid-European Clay Conference Zakopane, Poland, September 22-27, 2008].

[4] Fijał J., Gonet A., Stryczek S., Czekaj L.: Destabilization of colloidal microstructure of used drilling mud by reactive composites - management of treated wastes. Mineralogia - Special Papers, vol. 33, 2008, p. 58 [4th Mid-European Clay Conference, Zakopane, Poland, September 22-27, 2008].

[5] Gonet A., Czekaj L., Fijał J., Grzywnowicz I., Knez D., Rzyczniak, Stryczek S., Żurek R.: Metody przetwarzania organiczno-mineralnych odpadów wiertniczych w aspekcie ich zagospodarowania, ed. A. Gonet. Wydawnictwa AGH, Kraków 2006, pp. 3-230.

[6] Hudgins, C.: Chemical use in the North Sea oil and gas. E \& P. Journal Petroleum Technology, vol. 46, 1994.

[7] Jamrozik A.: Możliwości kompleksowego recyklingu odpadowych płuczek wiertniczych [Possibilities of complex recycling of drilling fluids waste]. Wydawnictwa AGH, Kraków 2009.

[8] Jamrozik A., Gonet A., Stryczek St, Czekaj L.: Possibilities and conditions for desalinization of drilling waste. AGH Drilling, Oil, Gas, vol. 27, 2010, pp. 183-192 [21 ${ }^{\text {st }}$ International Conference Oil-Gas AGH Zakopane, May 27-29, 2010].

[9] Jamrozik A., Gonet A., Fijał J., Terpiłowski K., Czekaj L.: Analysis of waste mud stability. AGH Drilling, Oil, Gas, vol. 31, no. 1, 2014.

[10] Neff J.M.: Composition, Environmental Fates, and Biological Effects of Water Based Drilling Muds and Cuttings Discharged to the Marine Environment: a Synthesis and Annotatet Bibliography. Petroleum Environmental Research Forum (PERF) and American Petroleum Institute, Batelle, Duxbury, MA 2005.

[11] Macnar K.: Badania wpływu składu i właściwości odpadów wiertniczych na dobór technologii recyklingu, odzysku lub unieszkodliwiania. PhD. Thesis, AGH University of Science and Technology, Faculty of Drilling, Oil and Gas, Krakow 2014.

[12] Wysocki S.: Floculation of bentonite suspensions and salted drilling mud with new cationic flocculants (PT-floc-201107). AGH Drilling, Oil, Gas, vol. 27, no. 4, 2010, pp. 759-764. 